\title{
CHEMICAL COMPOSITION OF RHIZOME OLEORESIN AND ANTI- INFLAMMATORY, ANTINOCICEPTIVE AND ANTIPYRETIC ACTIVITY OF OLEORESINS OF Alpinia allughas ROSCOE. FROM TARAI REGION OF UTTARAKHAND
}

\author{
Ravendra Kumar ${ }^{1 *}$, Sonali Sethi ${ }^{1}$, Om Prakash ${ }^{1}$, Anil Kumar Pant ${ }^{1}$, Mahesh Kumar ${ }^{2}$, \\ Valery A. Isidorov ${ }^{3}$, Lech Szczepaniak ${ }^{3}$
}

\author{
${ }^{1}$ Dept of Chemistry, College of \\ Basic Sciences and Humanities, \\ G.B. Pant Univ. Agriculture \& \\ Technology, Pantnagar, U.S. Nagar, \\ 263148 Uttarakhand, India \\ 2Dept of Vet. Epidemiology and \\ Preventive Medicine, College of \\ Veterinary \& Animal Sciences.G.B. \\ Pant Univ. of Agriculture \& \\ Technology, Pantnagar, U.S. Nagar, \\ 263148 Uttarakhand, India \\ Institute of Chemistry, Białystok \\ University, Division of \\ Environmental Chemistry, UL. \\ Hurtowa 1,15-399, Białystok, \\ Poland \\ Submitted:12-08-2016 \\ Revised: $19-02-2017$ \\ Accepted: 25-09-2017 \\ *Corresponding author \\ Ravendra Kumar \\ Email: \\ ravichemistry.kumar@gmail.com \\ oporgchem@gmail.com
}

\begin{abstract}
The investigation of volatile constituents of the rhizome oleoresin of Alpinia allughas Roscoe. growing in tarai region of Kumaun hills, Uttarakhand, revealed the presence of 55 terpenoids. The major constituents identified in the rhizome oleoresin were a-eudesmol (21.3\%), $\beta$-selinene $(13.9 \%)$, valencene $(9.6 \%)$, borneol $(7.1 \%)$, a-humulene (5.3\%)and7-epi-a-selinene (5.2\%). Other minor constituents identified were $(E)$ - $\beta$-caryophyllene $(3.8 \%)$, (6 $E)$-nerolidol $(3.5 \%),(E, E)$-farnesol $(3.2 \%)$, caryophyllene oxide $(2.5 \%)$, humulene oxide $(2.7 \%)$, bornyl acetate $(1.9 \%)$, coranarin- $E$ $(1.8 \%)$, linalool $(1.8 \%)$ and a-terpineol $(1.6 \%)$. The total identified constituents contribute $97.0 \%$ of the oleoresin. The rhizomes oleoresins exhibited significant antinociceptive activity with $34.79 \%$ inhibition at $50 \mathrm{mg} / \mathrm{kg} \mathrm{BW}$ and $43.24 \%$ at $100 \mathrm{mg} / \mathrm{kg}$ BW compared to standard drug ibuprofen $(40 \mathrm{mg} / \mathrm{kg} \mathrm{BW})$, it also showed antipyretic activity in dose dependent manner with temperature reduction $77.57 \pm 5.88 \%$ at $50 \mathrm{mg} / \mathrm{kg}$ BW and $98.95 \pm 3.95 \%$ at $100 \mathrm{mg} / \mathrm{kg}$ BW after $3 \mathrm{~h}$. Oleoresin also showed $29.23 \%$ inhibition of carrageenan-induced paw edema at $50 \mathrm{mg} / \mathrm{kg}$ BW. and $39.92 \%$ inhibition at $100 \mathrm{mg} / \mathrm{kg}$ BW in comparison to ibuprofen $40.06 \%$ at $40 \mathrm{mg} / \mathrm{kg} \mathrm{BW}$.
\end{abstract}

Keywords: $\quad$ a-eudesmol; $\quad \beta$-selinene; anti-inflammatory; antinociceptive; antipyretic activity

\section{INTRODUCTION}

The genus Alpinia (Zingiberaceae) comprises about 230 species originated mainly in the tropical Asian region and now also cultivated in many parts of the world (Loetschert and Beese, 1983; Lemmon and Sherman, 1964). Rhizome extracts of some zingiberaceous herbs are widely used in dietary intake and in the traditional herbal medicine (Chirangini et al., 2004).

It has been reported that Alpinia species possess antioxidant (Shi et al., 2006), antiinflammatory (Israf et al., 2007), anti-oxidant (Vankar et al., 2006), anticancer (Ali et al., 2001; Lee and Houghton, 2005), immunostimulating (Benjeddou et al., 2003), hepatoprotective (Kadota et al., 2003) and antinociceptive (Arambewela et al., 2004) activities. Further, the uses of rhizomes of Alpinia species (Alpinia galanga) in the digestive system, bronchitis, measles, rubella cholera and respiratory infections have been reported (Brown, 1995; Benjeddou et al., 2003).

Some zingiberaceous herbs have been reported to posses antibacterial (George and Pandalai, 1949), antifungal (Pushpangadan and Atal, 1984), anthelmintic activity (Kaleysa, 1975), antimicrobial activity (Robinson et al., 2009) in extracts and myorelaxant activity in essential oil (Panday et al., 2007) of Alpinia calcarata, antimicrobial and anti-inflammatory activity by diarylheptanoid from Alpinia officinarum (Subramanian et al., 2009) and antiplasmid activity by 1'-acetoxychavicol acetate from Alpinia galanga (Latha et al., 2009).

Essential oil of rhizome of $A$. allughas contained caryophyllene oxide $(23.07 \%)$, geraniol $(19.93 \%)$, citronellol $(6.8 \%), \quad \beta$ - 
caryophyllene $(5.45 \%), \quad \alpha$-pinene $(3.84 \%)$, linalool $(2.86 \%),(-) \alpha$-phellandrene $(1.6 \%)$ and geranyl acetate $(0.16 \%)$ (Purohit and Devi, 1976). Hence, the present study analyzed the chemical composition of the oleoresin and evaluated its in vitro anti-inflammatory, antinociceptive and antipyretic activities.

\section{MATERIALS AND METHODS \\ Plant material and extraction}

The rhizomes of Alpinia allughas Roscoe were collected in the month of November 2009, from the forest near Pantnagar located in tarai region of Kumaun hills, Uttarakhand, India. The specimen has been deposited in the Department of Chemistry, G.B. Pant University of Agric. \& Tech., Pantnagar, India. The identity of the plant was confirmed from Botany Division of Forest Research Institute, Dehradun, India where herbarium specimens Herbarium nos.: 9747 \& 72265 dated 12 Jan. 2004 have been deposited.

The oleoresin was extracted from Alpinia allughas rhizomes with the help of cold percolation method using ethanol, $1 \mathrm{~kg}$ of powdered rhizome were extracted for three times, the extracts were combined to evaporated under vacuum. The yield obtained was $112 \mathrm{~g}$ oleoresin. The oleoresin was stored in a refrigerator at $4^{\circ} \mathrm{C}$ for further use.

\section{GC-MS analysis of oleoresin}

On 10\% solution of oleoresin was prepared in $\mathrm{CH}_{2} \mathrm{Cl}_{2}$ and filtered to obtain a clear solution. GC-MS analysis of oleoresin solution $(0.2 \mu \mathrm{L})$ was performed using auto system XL (Perkin-Elmer, USA) fitted with Elite-5MS fused silica column $(30 \mathrm{~m} \times 0.25 \mathrm{~mm}$; $0.25 \mu \mathrm{m}$ film thickness), with the split-splitless injector. Helium flow rate through the column was $1 \mathrm{~mL} / \mathrm{min}$ in constant flow mode. The initial column temperature was $40^{\circ} \mathrm{C}$ rising $325^{\circ} \mathrm{C}$ at a rate $3^{\circ} \mathrm{C} / \mathrm{min}$. The $\mathrm{MS}$ detector temperature was $280^{\circ} \mathrm{C}$. The constituents were detected in the full scan mode from $\mathrm{m} / \mathrm{z} 41$ to 620.

A hexane solution of $\mathrm{C}_{8}-\mathrm{C}_{28} n$-alkanes was previously separated under the above conditions, and their retention times were determined. Linear temperature programmed retention indices (LTPRI) were calculated from the results of the separation of the oleoresin and $n$-alkanes according to eq.:

$$
\text { LTPRI }=\frac{100\left(t_{x}-t_{n}\right)}{\left(t_{n+1}-t_{n}\right)}+100 \mathrm{n}
$$

Where $t_{x}, t_{n}$ and $t_{n+1}$ are the retention times of component $x$, and $n$-alkanes with the number of carbon atoms in the molecule $n$ and $n+1$, respectively. After integration the fraction of each component in the total ion current (TIC) was calculated.

Components of oleoresin were identified with the help of NIST II, mass spectra library. Identification was considered reliable if the calculated values of LTPRI confirmed the results of library search at mass spectra library (LTPRIExp - LTPRILit $\leq 10$ index units) (Adams, 2007).

\section{Drugs and chemicals}

Carrageenan, acetic acid and formaldehyde were procured from Sigma Aldrich, Mumbai, India and Brewer yeast provided by India Glycols Limited, Kashipur, India. The reference drugs Ibuprofen, indomethacin and paracetamol were commercially purchased.

\section{Experimental animals}

The investigation of different biological activities of the extracts was carried out on Swiss strain albino mice weighing $18-23 g$ and purchased from the Indian Veterinary Research Institute (IVRI), Izatnagar, Bareilly, India. The mice were divided into different experimental groups. Each group consisted of six mice. All the groups were maintained under standard laboratory conditions of food and water. Prior to conduct the experiment, all the mice in each group were weighed individually to calculate the dose of drugs for each group. The animals were maintained in laboratory environment for two weeks to get them acclimatized. All experiments were conducted between 9 and 17h. All the animals were sustained under observation for one week, after the completion of experiments to observe acute or sub-acute toxicity, if any [Experiments protocols were approved by the institutional animal ethics committee, CPCSEA, New Delhi (Ref: $\mathrm{IAEC} / \mathrm{Chem} / \mathrm{CBSH} / 118)]$. 


\section{Animals and drugs model}

Total four different groups of mice with six in each group were taken for conducting various pharmacological activities. The experiments were conducted using two different doses (50mg/ $\mathrm{kg}$ and $100 \mathrm{mg} / \mathrm{kg}$ BW.). These concentrations were selected as per $\mathrm{IC}_{50}$ calculations. 50 and $100 \mathrm{mg}$ of oleoresins were separately triturated by the addition of small amount of Tween-20 and saline water was poured to make the final volume of $10 \mathrm{~mL}$. Ibuprofen, indomethacin and paracetamol were used as positive and saline water was as negative control respectively. The oleoresin, standard drug and saline water were given at the dose rate of the $0.1 \mathrm{~mL} / 10 \mathrm{gm}$ weight of the experimental animal.

\section{Anti-inflammatory activity Carrageenan produced hind paw edema \\ On $0.1 \mathrm{~mL}$ of $1 \%$ suspension of} carrageenan was injected to produces acute inflammation in the right hind paw of mice. The paw volume was measured by plethysmometer (UGO Basile, Italy) at 1, 3 and $24 \mathrm{~h}$ after the carrageenan injection. Ibuprofren solution at a dose of $80 \mathrm{mg} / \mathrm{kg}$ was given orally. The percentage reduction of edema was calculated in comparison to the control group (Winter et al., 1962; Vogel et al., 2007; Saini and Singhal, 2012).

\section{Formaldehyde induced arthritis}

The formaldehyde induced arthritis oleoresin was determined by following the method used by Selye, 1949. In brief $0.1 \mathrm{~mL}$ formaldehyde $(1 \%)$ solution was injected in the right hind paw of the mice on the first day for the experiment. Doses of the oleoresins (50 and $100 \mathrm{mg} / \mathrm{kg} \mathrm{BW}$ ) were administered orally daily in the morning till the end of the experiment study period for 10 days. Ibuprofen at a dose of $10 \mathrm{mg} / \mathrm{kg} \mathrm{BW}$ was orally given used as positive control while saline water was used as negative control. Finally, the paw volumes of all the experimental animals were recorded plethysmometrically in the evening hours for 10 days.

\section{Antinociceptive activity Writhing effect}

The pain sensation in mice was induced using an intraperitoneal injection of glacial acetic acid. At zero hour a calculated dose of $0.2 \mathrm{~mL}$ of oleoresins, $40 \mathrm{mg} / \mathrm{kg} \quad \mathrm{BW}$ of Ibuprofen was given orally. After 40min, glacial acetic acid $(1 \%$ at a dose of $0.1 \mathrm{~mL} / 10 \mathrm{gm} \mathrm{BW})$ was injected intraperitoneally to each animal. The number of writhings was counted in each animal for one minute including positive control. Finally, the percentage of pain inhibition was calculated as under

$\%$ writhing $=\frac{\mathrm{T}}{\mathrm{C}} \times 100$
$\%$ inhibition $=\frac{\mathrm{C}-\mathrm{T}}{\mathrm{C}} \times 100$

Where: $\mathrm{T}=$ treatments (group II-III) $\mathrm{C}=$ control saline group (I)

\section{Hot plate method}

The test was performed to measure analgesic response latencies as reported earlier by Langerman et al., 1995. In brief the hot-plate was sustained at $55.0 \pm 0.5^{\circ} \mathrm{C}$ and the mice were put into the perspex cylinder on the heated surface. The time in seconds to discomfort reaction was recorded as response latency, prior to and 30,60, 120, and 150min of 50 and $100 \mathrm{mg} / \mathrm{kg}$ BW oral administration of oleoresins. As a positive control, indomethacin $(50 \mathrm{mg} / \mathrm{kg} \mathrm{BW})$ and for negative control saline water $(0.2 \mathrm{~mL})$ was given orally. A latency period of the $20 \mathrm{~s}$. was remarketed as complete analgesia and the measurements were stopped if it exceeded the latency period to avoid injury.

\section{Brewer's yeast induced pyrexia}

To measure the antipyretic activity, pyrexia was induced using yeast as per the method is given by Rao et al., 1997 and generally being practiced. To record the basal body temperature a thermometer was inserted in to the rectum after restraining the mice. All the experimental groups were given a subcutaneous injection of $10 \mathrm{~mL} / \mathrm{kg} \mathrm{BW}$ of $20 \%$ suspension of Brewer's yeast (Saccharomyces cerevisiae) except control group. The mice were allowed to remain quiet in the cage for $18 \mathrm{~h}$, to rise in the body temperature. At the nineteenth hour again, the rectal temperature was recorded. Immediately, $0.1 \mathrm{~mL} / 10 \mathrm{gm} \mathrm{BW}$ of the oleoresins in the calculated doses of $50 \mathrm{mg} / \mathrm{kg}$ and $100 \mathrm{mg} / \mathrm{kg} \mathrm{BW}$ and paracetamol $(33 \mathrm{mg} / \mathrm{kg} \mathrm{BW})$ were given orally. Control group received $0.2 \mathrm{~mL}$ normal saline water only. 
The rectal temperature was recorded at hourly intervals in all the groups up to $3 \mathrm{~h}$. The percentage reduction in rectal temperature was calculated by considering the total fall in temperature to a normal level as $100 \%$.

$\%$ Temperature reduction $=\frac{\mathrm{B}-\mathrm{Cn}}{\mathrm{B}-\mathrm{A}} \times 100$

Where: $A=$ normal temp $B=$ Pyrexia temp $C=$ temp at hourly interval

\section{Toxicity}

The acute toxicity was performed according to OECD (The Organisation for Economic Co-operation and Development) guidelines (423, OECD/OCDE, 2001). Mortality was determined by giving oral doses of 400,600 and $800 \mathrm{mg} / \mathrm{kg} \mathrm{BW}$ of oleoresin. The change in the behaviour of animals was observed for two days and the numbers of deaths were recorded after up to four days.

\section{Statistical analysis}

Data were expressed as Mean \pm S.E. Results were analysed using one-way ANOVA and $\mathrm{p}<0.05$ was statically significant.

\section{RESULTS AND DISCUSSION Chemical composition of oleoresin}

The GC and GC-MS analysis of the oleoresin of $A$. allughas revealed more than 70 components out of which 63 compounds were identified. The total identified compound contributes to $96.6 \%$ of the oleoresin (Table I). The analysis of oleoresin from the rhizome of A. allughas was found to be rich in sesquiterpenes. The major constituents identified were $(E)$ - $\beta$-caryophyllene $(3.8 \%), \alpha$ humulene (5.3\%), $\beta$-selinene $(13.9 \%)$, valencene $(9.6 \%), \quad \alpha$-selinene $(1.1 \%), \quad 7-e p i-\alpha$-selinene (5.2\%), (6 E)-nerolidol (3.5\%), caryophyllene oxide $(2.5 \%)$, humulene oxide $(2.7 \%), \alpha-$ eudesmol $(21.3 \%)$, (E,E)-farnesol $(3.2 \%)$ and coranarin- $E(1.8 \%)$. The other constituents were in minor quantity, less than $1 \%$ (Table I). The major oxygenated monoterpenes identified included linalool $(1.8 \%)$, borneol $(7.1 \%), \alpha$ terpineol $(1.6 \%)$ and bornyl acetate $(1.9 \%)$.

Prakash et al., 2007 from our laboratory have reported $\beta$-pinene $(55.5 \%), \alpha$-pinene (9.7\%), 7-epi- $\alpha$-eudesmol (4.1\%), $\beta$-selinene (3.2\%), terpinene-4-ol $(2.2 \%), \quad 1,8$-cineole (2.1\%), $\alpha$-selinene (1.7\%), $\alpha$-humulene $(1.5 \%)$, $\beta$-caryophyllene $(1.1 \%)$ as the major constituents in the essential oil of $A$. allughas.

The present investigation revealed that the oloresin of Alpinia allughas analysed at the stage of maturity has different chemical make up than its essential oil isolated at an early stage before maturity. The monoterpenes content was lower at maturity while sesquiterpenes content increases.

\section{Anti-inflammatory assay Carrageenan induced hind paw edema}

Perusals of table II indicating that the oleoresin exhibited anti-inflammatory effect against the carrageenan induced paw edema in dose dependent manners. In carrageenan induced rat paw edema, administration of oleoresin reduced inflammation significantly from $4 \mathrm{~h}$ onwards compared to control group. The anti-inflammation at the dose level of $100 \mathrm{mg} / \mathrm{kg}$ BW was observed almost like ibuprofen.

\section{Formaldehyde induced arthritis}

In ibuprofen treated mice, a significant decrease in the paw volume was noticed from day 3 and value came to normal by day 10. Oleoresin $(50 \mathrm{mg} / \mathrm{kg}$ BW) showed a decrease in the sub-acute inflammation from day 5. The decrease in the formaldehyde induced arthritis from day 4 was observed at a dose level of $100 \mathrm{mg} / \mathrm{kg}$ BWof oleoresins. The inflammation reverted to normal after day 10 (Table III).

Carrageenan induces acute inflammation is essential for the detection of antiinflammatory activity in the drugs (Di Rosa and Willoughby, 1971). It has been reported that the edema is developed to carrageenan injection is a biphasic event. In first phase histamine and serotonin are released while in phase two $(3-5 \mathrm{~h})$ is said to be synergised by prostaglandins. The edema is maintained between first and second phase due to kinin. It has also been reported that the second phase edema is sensitive to clinically effective steroids and non-steroids anti-inflammatory agents (Vinegar et al., 1969; Ramachandran et al., 2011)

Alpinia allughas oleoresin used in this study, revealed anti-inflammatory activity probably due to the inhibition of the cyclooxygenage pathway. It has been reported that 
Table I. Comparative chemical composition (\%) of Alpinia allughas Roscoe. rhizome oleoresin and essential oil.

\begin{tabular}{|c|c|c|c|c|}
\hline S.N. & Compounds & LTPRIExp & $\begin{array}{c}\text { Oleoresin } \\
(\%)\end{array}$ & $\begin{array}{c}\text { Essential oil } \\
(\%) \dagger\end{array}$ \\
\hline 1 & (Z)-2-hexen-1-ol & 859 & $t$ & - \\
\hline 2 & 2-methyl-2-heptanone & 921 & 0.1 & - \\
\hline 3 & $\alpha$-thujene & 931 & - & 0.2 \\
\hline 4 & $\alpha$-pinene & 939 & - & 9.7 \\
\hline 5 & camphene & 953 & - & 0.5 \\
\hline 6 & acetylcyclohexane & 962 & 0.1 & - \\
\hline 7 & sabinene & 970 & $\mathrm{t}$ & $\mathrm{t}$ \\
\hline 8 & $\beta$-pinene & 975 & $\mathrm{t}$ & 55.3 \\
\hline 9 & myrcene & 991 & - & 0.4 \\
\hline 10 & $p$-cymene & 1022 & $\mathrm{t}$ & - \\
\hline 11 & limonene & 1027 & $\mathrm{t}$ & $\mathrm{t}$ \\
\hline 12 & 1,8-cineole & 1029 & 0.3 & 2.1 \\
\hline 13 & $\gamma$-terpinene & 1056 & - & 1.0 \\
\hline 14 & cis-sabinene hydrate & 1067 & 0.1 & - \\
\hline 15 & terpinolene & 1088 & - & 0.2 \\
\hline 16 & linalool & 1098 & 1.8 & 0.5 \\
\hline 17 & nonanal & 1103 & 0.2 & - \\
\hline 18 & cis-p-menth-2-ene-1-ol & 1122 & 0.1 & - \\
\hline 19 & nopinone & 1135 & 0.1 & - \\
\hline 20 & cis-sabinol & 1137 & 0.1 & - \\
\hline 21 & camphor & 1143 & 0.2 & - \\
\hline 22 & pinocarvone & 1159 & 0.1 & - \\
\hline 23 & borneol & 1168 & 7.1 & - \\
\hline 24 & terpinen-4-ol & 1177 & 3.7 & 2.2 \\
\hline 25 & p-cymen-8-ol & 1184 & 0.1 & - \\
\hline 26 & $\alpha$-terpineol & 1192 & 1.6 & - \\
\hline 27 & linalyl acetate & 1248 & 0.6 & - \\
\hline 28 & bornyl acetate & 1281 & 1.9 & - \\
\hline 29 & $\alpha$-terpenyl acetate & 1343 & 0.4 & - \\
\hline 30 & $\alpha$-cubebene & 1351 & - & $\mathrm{t}$ \\
\hline 31 & cis-carvone oxide & 1357 & 0.1 & - \\
\hline 32 & $\alpha$-copaene & 1372 & 0.1 & - \\
\hline 33 & geranyl acetate & 1376 & 0.1 & - \\
\hline 34 & $(E)$ - $\beta$-elemene & 1386 & 0.1 & - \\
\hline 35 & $(E)-\beta$-caryophyllene & 1415 & 3.8 & - \\
\hline 36 & $\alpha$-guaiene & 1441 & 0.1 & - \\
\hline 37 & $\alpha$-humulene & 1451 & 5.3 & 1.5 \\
\hline 38 & $\beta$-selinene & 1485 & 13.9 & 3.2 \\
\hline 39 & valencene & 1488 & 9.6 & - \\
\hline 40 & $\alpha$-selinene & 1491 & 1.1 & 1.7 \\
\hline 41 & $(E, E)-\alpha$-farnesene & 1502 & 0.3 & - \\
\hline 42 & 7-epi- $\alpha$-selinene & 1514 & 5.2 & - \\
\hline 43 & (6E)-nerolidol & 1558 & 3.5 & - \\
\hline 44 & caryophyllene oxide & 1576 & 2.5 & - \\
\hline
\end{tabular}




\begin{tabular}{|c|c|c|c|c|}
\hline S.N. & Compounds & LTPRIExp & Oleoresin $(\%)$ & Essential oil $(\%) \dagger$ \\
\hline 45 & $n$-hexadecane & 1600 & 0.1 & - \\
\hline 46 & humulene oxide & 1603 & 2.7 & - \\
\hline 47 & 10-epi- $\gamma$-eudesmol & 1616 & 0.1 & - \\
\hline 48 & 1-epi-cubenol+ allohedycariol & 1625 & 0.4 & - \\
\hline 49 & 3-iso-thujopsanone & 1629 & 0.1 & - \\
\hline 50 & $\delta$-cadinol & 1639 & 0.2 & - \\
\hline 51 & $\beta$-eudesmol & 1648 & 0.4 & - \\
\hline 52 & $\alpha$-cadinol & 1650 & 0.4 & - \\
\hline 53 & selin-11-en- $4 \alpha$-ol & 1652 & - & $\mathrm{t}$ \\
\hline 54 & $\alpha$-eudesmol & 1658 & 21.3 & - \\
\hline 55 & 7-epi- $\alpha$-eudesmol & 1662 & - & 4.1 \\
\hline 56 & aromadendrene oxide & 1667 & 0.7 & - \\
\hline 57 & 6-hydroxycaryophyllene & 1669 & 0.4 & - \\
\hline 58 & $(E, Z)$-farnesol & 1742 & 0.2 & - \\
\hline 59 & (Z)-lanceol & 1758 & 0.1 & - \\
\hline 60 & $(E, E)$-farnesol & 1790 & 3.2 & - \\
\hline 61 & farnesyl acetate & 1845 & 0.1 & - \\
\hline 62 & occidol acetate & 1971 & 0.1 & - \\
\hline \multirow[t]{2}{*}{63} & coranorin-E & 2112 & 1.8 & - \\
\hline & Total & & $96.6 \%$ & $83.7 \%$ \\
\hline
\end{tabular}

$\mathrm{t}=$ trace $>0.01 \%,+$ Prakash et al. $(2007)$

Table II. Anti-inflammatory activity of oleoresin of Alpinia allughas: carrageenan-induced paw edema (Mean \pm SE, $\mathrm{N}=6$ )

\begin{tabular}{ccccc}
\hline \multirow{2}{*}{ Treatment } & \multirow{2}{*}{ Dose $(\mathbf{m g} / \mathbf{k g ~ B W})$} & \multicolumn{2}{c}{ Change in paw thickness } & \multirow{2}{*}{$\mathbf{0}$ Inhibition } \\
\hline Control & 0 & $2.18 \pm 0.02$ & $2.17 \pm 0.04$ & 00.48 \\
Ibuprofen & 40 & $2.97 \pm 0.05$ & $1.78 \pm 0.04^{\mathrm{a}}$ & 40.06 \\
Oleoresin & 50 & $2.60 \pm 0.08$ & $1.84 \pm 0.08^{\mathrm{b}}$ & 29.23 \\
Oleoresin & 100 & $2.58 \pm 0.08$ & $1.55 \pm 0.17 \mathrm{~b}$ & 39.92 \\
\hline
\end{tabular}

$\mathrm{a}=$ significant $(\mathrm{p}<0.05)$ compared to control; $\mathrm{b}=$ significant $(\mathrm{p}<0.05)$ compared to ibuprofen

the anti-inflammatory activity of the drug is due to its interference with the production of prostaglandins (Smith and Willis, 1971; Seibert et al., 1994). In the present report the oleoresins of $A$. allughas showed a dose dependent effect on paw volume thickness at the dose level of $50 \mathrm{mg} / \mathrm{kg} \mathrm{BW}$ and $100 \mathrm{mg} / \mathrm{kg} \mathrm{BW}$ respectively compared to ibuprofen (Table II).

For studying sub-acute antiinflammatory activity, arthritis was produced by using formaldehyde on day one of the experiment and the test samples were given orally every day for 10 days. The significant anti-artritis effect was observed during present investigation.
Several essential oil components are reported to exhibit 5-lipoxygenage inhibitors which include $\beta$-caryophyllene (Kamatou et al., 2006), $\alpha$-bisabolol (Kamatou and Viljoen, 2010). These compounds have been reported to possess anti-inflammatory activity due to the inhibition of leukotriene synthesis. The rhizome of Alpinia murdochii Ridl., Alpinia scabra (Blume) naves and leaves of Alpinia pahangensis Ridl. have been reported to exhibit 5lipoxygenage inhibitor activity (Syamsir, 2009). The sesquiterpenes santoline, spathulenol, caryophyllene oxide, $\alpha$-humelene, kaurene, elemol, $\gamma$-eudesmolandsabineneetc. Have been reported to possess anti-inflammatory activity 
Table III. Effect of oleoresins of Alpinia allughas on formaldehyde induced arthritis (Mean \pm SE, $\mathrm{N}=6$ )

\begin{tabular}{|c|c|c|c|c|c|c|c|c|c|c|c|c|}
\hline \multirow[b]{2}{*}{ Treatment } & \multirow{2}{*}{$\begin{array}{c}\text { Dose } \\
(\mathrm{mg} / \mathrm{kg})\end{array}$} & \multicolumn{10}{|c|}{ Volume of inflammation } & \multirow[b]{2}{*}{$\begin{array}{c}\text { Day } \\
10\end{array}$} \\
\hline & & Day & Day & Day & Day & Day & Day & Day & Day & Day & Day & \\
\hline \multirow{4}{*}{ Control } & \multirow{4}{*}{0} & 2.14 & 2.20 & 2.16 & 2.25 & 2.15 & 2.18 & $2.16 \pm$ & 2.29 & 2.16 & 2.19 & 2.23 \\
\hline & & \pm & \pm & \pm & \pm & \pm & \pm & 0.15 & \pm & \pm & \pm & \pm \\
\hline & & 0.06 & 0.10 & 0.13 & 0.12 & 0.07 & 0.08 & & 0.11 & 0.12 & 0.11 & 0.13 \\
\hline & & 2.18 & 2.35 & 2.28 & 2.34 & 2.31 & 2.31 & 2.29 & 2.28 & 2.26 & 2.17 & 2.16 \\
\hline \multirow[t]{3}{*}{ Ibuprofen } & \multirow[t]{3}{*}{10} & \pm & \pm & \pm & \pm & \pm & \pm & \pm & \pm & \pm & \pm & \pm \\
\hline & & 0.08 & $0.09^{a}$ & 0.12 & 0.03 & $0.08^{a}$ & $0.11^{a}$ & 0.10 & 0.10 & 0.09 & 0.05 & 0.06 \\
\hline & & 2.12 & 2.30 & 2.28 & 2.26 & 2.26 & 2.24 & 2.23 & 2.21 & 2.18 & 2.10 & 2.16 \\
\hline \multirow[t]{3}{*}{ Oleoresin } & \multirow[t]{3}{*}{50} & \pm & \pm & \pm & \pm & \pm & \pm & \pm & \pm & \pm & \pm & \pm \\
\hline & & 0.05 & 0.03 & 0.02 & 0.02 & $0.04^{a}$ & 0.04 & 0.02 & 0.02 & 0.08 & 0.07 & 0.07 \\
\hline & & 2.09 & 2.20 & 2.24 & 2.24 & 2.22 & 2.22 & 2.21 & 2.21 & 2.20 & 2.10 & 2.18 \\
\hline \multirow[t]{2}{*}{ Oleoresin } & \multirow[t]{2}{*}{100} & \pm & \pm & \pm & \pm & \pm & \pm & \pm & \pm & \pm & \pm & \pm \\
\hline & & 0.06 & 0.11 & 0.11 & 0.11 & 0.11 & 0.10 & 0.09 & 0.08 & 0.07 & 0.06 & 0.06 \\
\hline
\end{tabular}

$\mathrm{a}=$ significant $(\mathrm{p}<0.05)$ compared to control ${ }^{\mathrm{b}}=$ significant $(\mathrm{p}<0.05)$ compared to ibuprofen

Table IV. Peripheral analgesic activity of oleoresins of Alpinia allughas (Writhing Effect) (Mean \pm SE, $\mathrm{n}=6$ )

\begin{tabular}{lcccc}
\hline Treatment & Dose $\mathbf{( m g} / \mathbf{k g ~ B W})$ & No of Writhings & \% Writhing & \% Inhibition \\
\hline Control & 0 & $217.00 \pm 1.26$ & 100.00 & 0 \\
Ibuprofen & 40 & $123.50 \pm 3.44$ & 56.91 & 43.08 \\
Oleoresin & 50 & $141.50 \pm 1.37$ & 65.20 & $34.79 \mathrm{a}$ \\
Oleoresin & 100 & $123.16 \pm 0.40$ & 56.75 & 43.24 \\
\hline
\end{tabular}

${ }^{a}=$ significant $(\mathrm{p}<0.05)$ compared to ibuprofen

(Medeiros et al.; Fernandes et al., 1994; Chao et al., 2005; Yoon et al., 2009).

\section{Antinociceptive assay Writhing effect}

Oleoresin showed significant peripheral analgesic activity in writhing effect with $34.79 \%$ reduction at a dose level of $50 \mathrm{mg} / \mathrm{kg}$ BW and $43.24 \%$ at a dose level of $100 \mathrm{mg} / \mathrm{kg} \mathrm{BW}$ respectively compared to ibuprofen (Table IV).

\section{Hot plate method}

A perusal of table $\mathrm{V}$ reveals that the discomfort reaction time in indomethacin treated mice was maximum at $60 \mathrm{~min}$ while oleoresins exhibited a dose dependent manner increase in the paw licking and jumping time. In the present study the oleoresins significantly attenuated the response in a dose dependent manner.
1, 8-cineole a major constituent of the essential oils of most Eucalyptus species and also present in our plant exhibit antinociceptive effect by reducing the acetic acid-induced pain sensation in experimental animal (Santos and Rao, 2000). It has been reported that 1,8cineole inhibited the paw licking response in both the phases of formalin test, with a significant inhibition only at the second phase (de Limaet al., 2009).

$(-)$-Linalool is a monoterpene present in aromatic plants viz; Oscimum basilicum, Origanum vulgare, Aeolant hussuaveolens and also marker compounds of zingiberaceous herbs. The antinociceptive activity of linalool in inflammation and neuropathic pains has been reported. It has been reported that the monoterpene significantly reduced the acid-induced writhing and in the hot plate test (Peana et al., 2004). Batista et al., 2010 also reported the significant 
Table V. Central analgesic activity of oleoresins of Alpinia allughas (Hot plate method) (Mean \pm SE, $\mathrm{n}=6)$

\begin{tabular}{lcccccc}
\hline \multirow{2}{*}{ Treatment } & Dose & \multicolumn{5}{c}{ Hot plate reaction time (min) } \\
\cline { 3 - 7 } & $\mathbf{( m g / k g ~ B W )}$ & $\mathbf{0}$ & $\mathbf{3 0}$ & $\mathbf{6 0}$ & \multicolumn{1}{c}{$\mathbf{2 0}$} & $\mathbf{1 5 0}$ \\
\hline Control & 0 & $3.01 \pm 0.00$ & $3.11 \pm 0.01$ & $2.95 \pm 0.01$ & $2.84 \pm 0.02$ & $3.03 \pm 0.02$ \\
Indomethacin & 50 & $3.27 \pm 0.03$ & $3.83 \pm 0.03^{\mathrm{a}}$ & $4.93 \pm 0.04^{\mathrm{a}}$ & $4.07 \pm 0.09^{\mathrm{a}}$ & $3.84 \pm 0.03^{\mathrm{a}}$ \\
Oleoresin & 50 & $2.71 \pm 0.09$ & $2.24 \pm 0.02^{\mathrm{a}, \mathrm{b}}$ & $2.91 \pm 0.05^{\mathrm{b}}$ & $2.78 \pm 0.07^{\mathrm{b}}$ & $2.60 \pm 0.08^{\mathrm{a}, \mathrm{b}}$ \\
Oleoresin & 100 & $2.79 \pm 0.09$ & $3.23 \pm 0.05^{\mathrm{b}}$ & $2.75 \pm 0.12^{\mathrm{a}, \mathrm{b}}$ & $3.23 \pm 0.08^{\mathrm{a}, \mathrm{b}}$ & $3.04 \pm 0.05^{\mathrm{b}}$ \\
\hline
\end{tabular}

$\mathrm{a}=$ significant $(\mathrm{p}<0.05)$ compared to control; $\mathrm{b}=$ significant $(\mathrm{p}<0.05)$ compared to indomethacin

Table VI. Effect of oleoresins of Alpinia allughas on Brewer's yeast induced pyrexia in mice (Mean \pm SE, $N=6)$

\begin{tabular}{|c|c|c|c|c|c|c|}
\hline \multirow[b]{2}{*}{ Treatment } & \multirow[b]{2}{*}{$\begin{array}{c}\text { Dose } \\
(\mathrm{mg} / \mathrm{k})\end{array}$} & \multicolumn{2}{|c|}{ Body temperature $\left({ }^{0} \mathrm{C}\right)$} & \multicolumn{3}{|c|}{$\begin{array}{c}\text { Temperature after administration of } \\
\text { drug }\left({ }^{\circ} \mathrm{C}\right)\end{array}$} \\
\hline & & $\begin{array}{c}\text { Before } \\
\text { injection of } \\
\text { Brewer's yeast }\end{array}$ & $\begin{array}{c}\text { After } \\
\text { injection of } \\
\text { Brewer's yeast }\end{array}$ & $1 \mathrm{hr}$ & $2 \mathrm{hr}$ & $3 \mathrm{hr}$ \\
\hline Control & 0 & $37.55 \pm 0.02$ & $38.87 \pm 0.03$ & $\begin{array}{l}38.87 \pm 0.03 \\
(2.36 \pm 1.07)\end{array}$ & $\begin{array}{l}38.89 \pm 0.03 \\
(3.77 \pm 5.46)\end{array}$ & $\begin{array}{l}38.81 \pm 0.03 \\
(6.05 \pm 3.70)\end{array}$ \\
\hline Paracetamol & 33 & $37.53 \pm 0.06$ & $38.82 \pm 0.04$ & $\begin{array}{l}37.63 \pm 0.04^{\mathrm{a}} \\
(92.86 \pm 3.28)\end{array}$ & $\begin{array}{l}37.54 \pm 0.02^{\mathrm{a}} \\
(99.47 \pm 5.49)\end{array}$ & $\begin{array}{c}37.49 \pm 0.01^{\mathrm{a}} \\
(103.60 \pm 5.20)\end{array}$ \\
\hline Oleoresin & 50 & $37.54 \pm 0.05$ & $38.79 \pm 0.07$ & $\begin{array}{l}38.10 \pm 0.04 \mathrm{a} \\
(56.66 \pm 6.31)\end{array}$ & $\begin{array}{l}38.02 \pm 0.05^{\mathrm{a}, \mathrm{b}} \\
(62.50 \pm 2.76)\end{array}$ & $\begin{array}{l}37.84 \pm 0.07 \mathrm{a}, \mathrm{b} \\
(77.57 \pm 5.88)\end{array}$ \\
\hline Oleoresin & 100 & $37.56 \pm 0.05$ & $38.86 \pm 0.04$ & $\begin{array}{c}37.81 \pm 0.08 \mathrm{a}, \mathrm{b} \\
(80.49 \pm 7.66)\end{array}$ & $\begin{array}{c}37.68 \pm 0.06^{\mathrm{a}, \mathrm{b}} \\
(90.75 \pm 6.57)\end{array}$ & $\begin{array}{c}37.57 \pm 0.06^{\mathrm{a}, \mathrm{b}} \\
(98.95 \pm 3.90)\end{array}$ \\
\hline
\end{tabular}

Percentage reduction in temperature is given within parenthesis

$\mathrm{a}=$ significant $(\mathrm{p}<0.05)$ compared to control; $\mathrm{b}=$ significant $(\mathrm{p}<0.05)$ compared to paracetamol

antinociceptive effects of linalool in mice, specifically in mechanical hypersensitivity induced by the neuropathic pain and in the mechanical and cold hypersensitivity induced by a chronic inflammatory model. Similarly, borneol also present in our sample reported to posses antinociceptive activity (Almeida et al., 2013).

The antinociceptive effect of farnesol conducted by acetic acid-induced writhings and formalin assays has also been reported by Oliveira et al., 2013.Similarly Paula-Freire et al., 2014 has reported the antinociceptive properties of $(E)$-caryophyllene.

It has been reported that the pharmacological activities of Copaiba oleoresin were because of the presence of sesquiterpenes like $\beta$-caryophyllene, caryophyllene oxide, $\alpha$ humulene, $\delta$-cadinene, $\alpha$-cadinol, $\alpha$ - and $\beta$ selinene, $\beta$-elemene, $\alpha$-copaene and $\alpha$-eudesmol (Leandro et al., 2012). These compounds are also identified in present analysis of $A$. allughas oleoresin. However, the other constituents including minor once in the oleoresin may interact synergistically in the promotion of the observed pharmacological activities.

\section{Brewer's yeast induced pyrexia}

The oleoresin of $A$. allughas showed a reduction in body temperature in Brewer's yeast induced pyrexia in mice. Oleoresin produced a significant antipyretic effect in a dose dependent manner with $50 \mathrm{mg} / \mathrm{kg}$ BW and $100 \mathrm{mg} / \mathrm{kg}$ BWdose level. Negative control mice did not show any reduction in the body temperature on oral administration of saline. The maximum inhibition was observed at $3 \mathrm{~h}$ (Table VI).

An appreciable antipyretic effect was noticed in oleoresins in dose dependent manner which was comparable to paracetamol. Previous studies reveal that lipid peroxidation 
process is responsible to increase body temperature. We have also reported antioxidant activity of Alpinia allughas which may be responsible for the activity observed in the experiments (Sethi et al., 2015). The antioxidant supplementation decreases the lipid peroxidation processes hence reduce pyrexia (Brzezinska-Slebodziniska, 2001).

Oleoresins of Alpinia allughas possess significant anti-inflammatory, anti-nociceptive and antipyretic properties, which can be used for the preparation of various formulations for the treatment of inflammation, pain and pyrexia.

\section{Toxicity}

On giving oral doses of 400, 600, $800 \mathrm{mg} / \mathrm{kg} \mathrm{BW}$ of Alpinia allughas oleoresin, no change in behaviour or physiology was observed for two days and on a subsequent day. No lethality was observed during the experiment. All reflexes (pedal and corneal) and rectal temperature as well heart, respiration rates were within normal physiological limits in the extract treated mice.

\section{CONCLUSION}

The results suggest that Alpinia allughas, the member of family Zingiberaceae can be utilized for its chemical constituents and pharmaceutical activities. Being a wild plant species of this region, it can be taken for commercial cultivation and exploitation for use as herbal drug and source of perfumery chemicals.

\section{ACKNOWLEDGMENT}

Thanks are due to U.G.C., New Delhi, India for a research fellowship to Ravendra Kumar and Summer Chandra F.R.I. Dehradun, India for plant identification.

\section{REFRENCES}

Adams RP., 2007. Identification of essential oil components by gas chromatography/ mass Spectrometry, $4^{\text {th }}$ Edition.Allured Business Media Publishing Corporation, Carol Stream, Illinois, USA.

Ali MS., Banskota AH., Tezuka Y., Saiki I., Kadota S. 2001.Antiproliferative activity of diarylheptanoids from the seeds of
Alpinia blepharocalyx. Bio. Pharm. Bull. 24:525-528.

Almeida JR GdaS., Souza GR., Silva JC., Saraiva SR GdeL., Júnior R Gde O., QuintansJde SS., et al., 2013. Borneol, a Bicyclic Monoterpene Alcohol, Reduces Nociceptive Behavior and Inflammatory Response in Mice.The Sci. Wor.J. 2013:15.

Arambewela LSR., Arawwawala LDAM., Ratnasooriya WD. 2004. Antinociceptive activities of aqueous and ethanolic extracts of Alpinia calcarata rhizomes in rats.J. Eth.pharm. 95:311-331.

Batista PA., Werner MFP., Oliveira EC., Burgos L., Pareira P., Brum LFS., Story GM., Santos ARS. 2010. The antinociceptive effect of (-)-linalool in models of chronic inflammatory and neuropathic hypersensitivity in mice. J. Pain.11:1222.

Bendjeddou D., Lalaoui K., Satta D. 2003. Immunostimulating activity of the hot water-soluble polysaccharide extracts of Anacyclus pyrethrum, Alpinia galangal and Citrullus colocynthis.J. Eth. pharm.88:155-160.

Brown D. 1995. In: Kinderstey, D. (Ed.), the Royal Horticultural Society Encyclopedia of Herbs and their Uses. London. pp. 235-237.

Brzezinska-Slebodzinska E. 2001.Fever induced oxidative stress. The effect on thyroid status and the 5'-mono deiodinase activity, protective role of selenium vitamin.J. Phys. Pharm. 52:275-284.

Chirangini P., Sharma GJ.,Sinba., Swapan K. 2004. Sulfur free radical reactivity with curcumin as reference for evaluating antioxidant properties of medicinal Zingiberales. J. Env.Path.Tox. Onc. 23(3):227-236.

Chao LK.,Hua KF., Hsu HY., Cheng SS., Liu JY. Chang ST. 2005. Study of the antiinflammatory activity of essential oil from leaves of Cinnamomum osmophloeum. J. Ag. Food Chem.53:7274-7278.

de Lima AB., Santana MB., Cardoso AS., da Silva JKR., Maia JGS., Sousa PJCC. 2009. Antinociceptive activity of 1-nitro2- phenylethane, the main component of 
Aniba canelilla essential oil.Phyt.med. 16:555-559.

Di Rosa M., Willoughby DA. 1971. Screens for anti-inflammatory drugs. J. Pharm. Pharm. 23:297-298.

George M., Pandalai KM. 1949. Investigation of plant antibiotics. Ind. J. Med. Res. 37: 169-181.

Fernandes ES., Passos GF., Medeiros R., da Cunha FM., Ferreira J., et al., 2007. Antiinflammatory effects of compounds alpha-humulene and (-)-transcaryophyllene isolated from the essential oil of Cordia verbenacea. Eur. J. Pharm.569:228-236.

Israf DA., KhaizurinTA., Syahida A., Lajis NH., Khozirah S. 2007. Cardamonin inhibits COX and iNOS expression via inhibition of p65NF-kappaB nuclear translocation and Ikappa-B phosphorylation in RAW 2647 macrophage cells. Mol. Immun. 44:673-679.

Kadota S., Tezuka Y., PrasainJK., Ali MS., Banskota, AH. 2003. Novel diarylheptanoids of Alpinia blepharocalyx. Cur.Top. Med. Chem. 3:203-225.

Kaleysa RR. 1975. Screening of indigenous plants for anthelmentic action against human Ascaris lumbricoides. Ind. J. Phys. Pharm. 19:47-49.

Kamatou GPP.,Viljoen AM. 2010. A review of the application and pharmacological properties of $\alpha$-bisabolol and $\alpha$ bisabolol-rich oils. J. Am. Oil Chem. Soc.87:1-7.

Kamatou GPP., van Zyl RL., van Vuuren SF., Viljoen AM., Figueiredo AC., et al., 2006. Chemical composition, leaf trichome types and biological activities of the essential oils of four related Salvia species indigenous to Southern Africa. J. Ess. Oil Res.18:72-79.

Langerman L., Zakowski MI., Piskoun B., Grant GJ. 1995. Hot plate versus tailflick: Evaluation of acute tolerance to continuous morphine infusion in rat model. J. Pharm. Tox. Meth.34:23-27.

Lathaa C., Shriram VD., Jahagirdar SS., Dhakephalkar PK., Rojatkara, SR. 2009. Antiplasmid activity of 1'-acetoxychavicol acetate from $A$. galangal against multi-drug resistant bacteria.J. Eth.pharm. 123:522-525.

Leandro LM., Vargas FdeS., Barbosa PCS., Neves JKO., Silva JAda., Junior VFdaV. 2012. Chemistry and Biological Activities of Terpenoids from Copaiba (Copaiferas pp.) Oleoresins. Molecule.17.3866-3889.

Lee CC., Houghton P. 2005. Cytotoxicity of plants from Malaysia and Thailand used traditionally to treat cancer. J. Ethn. 100:237-243.

Lemmon RS., Sherman CL. 1964. Flowers of the World, Doubleday, New York.

Loetschert W., Beese, G. 1983. Guia de las Planta s'Tropicales, Ed. Omega, Barcelona.

Medeiros R., Passos GF., Vítor CE., Koepp J., Mazzuco TL., Pianowski LF., Campos MM., Calixto JB. 2007. Effect of two active compounds obtained from the essential oil of Cordia verbenaceaon the acute inflammatory responses elicited by LPS in the rat paw. Brit. J.Pharmacol. 151:618-627.

Saini NK., Singhal M. 2012. Anti-inflammatory, analgesic and antipyretic activity of methanolic Tecomaria capensis leaves extract. Asian Pac. J. Trop. Biomed. 2(11): 870-874

Oliveira Jr WM., Benedito RB., Pereira WB., Torres PA., Ramos CAF., et al., 2013. Farnesol: antinociceptive effect and histopathological analysis of the striatum and hippocampus of mice. Fundam. Clin. Pharmacol. 27:419.423, OECD/OCDE. 2001. Acute oral toxicity-Acute toxic class method. Guideline for the testing of chemicals, guidance document on acute toxic class method.

Paula-Freire LIG., Andersen ML., Gama VS., Molska GR., Carlini ELA. 2014. The oral administration of trans-caryophyllene attenuates acute and chronic pain in mice. Phyt. Med.21:356-362.

Pandey S., Prakash O., Zafar A., Hore SK., Pant AK., Mathela CS. 2007. Myorelaxant effect of essential oil of rhizome of Alpiniacalcarata Rosc. on rat duodenal smooth muscle. Nat. Prod. Comm. 2(7):789-793.

Peana AT., MontisMG.,Sechi S., Sircana G., D'Aquila PS., Pippia P. 2004. Effects of (-)-linalool in the acute hyperalgesia 
induced by carrageenan, L-glutamate and prostaglandin E2.Eur. J. Pharmacol. 497(3): 279-284.

Prakash O., Joshi S., Pant AK., Chanotiya CS., Mathela CS. 2007. Volatile Constituents of Rhizomes and Leaves of Alpiniaallughas Roscoe. J. Essnt. Oil Res. 19(5): 407-409.

Purohit RM, Devi K. 1976. Chromatographic analysis of the essential oil from the rhizome of Alpiniaallughas. Riechst Aromen, Koerperflegem. 26(7):139-142.

Pushpangadan P., Atal CK. 1984. Ethen medico botanical investigations in Kerela.J. Ethn. 111:59-77.

RaoRR.,Babu RM., Rao, MRV., Babu, MGV. 1997. Studies on antipyretic, analgesic and hypoglycaemic activities of root of Gynandropsisgynandra Linn. Ind. Drug. 34(12):690- 694.

Ramachandran S., Rajinikanth B., Rajasekaran A., Manisenthil Kumar KT. 2011. Evaluation of anti-inflammatory and analgesic potential of methanol extracts of Tectonagrandis flowers. Asian Pac. J. of Trop. Biomed.S155-S158.

Robinson JP.,Balakrishnan V., Raj JS. 2009. Antimicrobial activity of AlpiniacalcarataRosc. and characterization of new $\alpha, \quad \beta$ unsaturated carbonyl compounds. Adv. Bio. Res. 3(5-6):185187.

Santos FA.,Rao VS. 2000. Antiinflammatory and antinociceptive effects of 1,8-cineole a terpenoid oxide present in many plant essential oils.Phyto. Res. 14(4):240-244.

Seibert K., Zhang Y., Leahy K., Hauser S., Masferrer J., Perkins W. 1994. Pharmacological and biochemical demonstration of the role of cyclooxygenase 2 in inflammation and pain.Pro. Nat. Aca. Sci. 91:12013-12017.

Selye H. 1949. Further studies concerning participation of the adrenal cortex in the pathogenesis of the arthritis. Brit. Med. Jour. 2:1129-1135.

Shi GF., An LJ., Jiang., Guan S., Bao YM. 2006. Alpinia protocatechuic acid protects against oxidative damage in vitro and reduces oxidative stress in vivo. Neur. Lett. 403:206-210.
Smith JB., Willis AL. 1971. Aspirin selectivity inhibition prostaglandin production in human platelets.Nat.New Bio.231:235239.

Sethi S., Prakash O., Pant AK. 2015. Essential oil composition, antioxidant assay and antifungal activity of essential oil and various extracts of Alpinia allughas (Retz.) Roscoe leaves. Cogent Chem. 1:1079349.

Subramanian K., Selvakkumar C., Vinaykumar KS., Goswami N., Meenakshisundaram S., Balakrishnan, A. 2009. Tackling multiple antibiotic resistances in enteropathogenic Escherichia coli (EPEC) clinical isolates: a diarylheptanoid from Alpinia officinarums hows promising antibacterial and immunomodulatory activity against EPEC and its lipopolysaccharide-induced inflammation. Int. J. Anti. Agen. 33:244-250.

Syamsir DRB. 2009. Essential oils and biological activities of three selected wild Alpinia species. Master thesis, Institute of Biological Sciences, Faculty of Sciences, University of Malaya, Kuala Lumpur, Malaysia.

Vankar PS., Vandana T., Singh LW., Ningombam S. 2006. Antioxidant properties of some exclusive species of Zingiberaceae family of Manipur.Elec. J. Env. Ag. Food Chem. 5(2):1318-1322.

Vinegar R., Schreiber W., Hugo R. 1969. Biphasic development of carrageenan edema in rats. J. Pharm. Exp. Therap. 166(1):96-103.

Vogel HG., Scholkens BA., Sandow J., Muller G., Vogel WH. 2007. Drug discovery and evaluation. Berlin Heidelberg: Springer-Verlag;

Winter CA., Risley EA., Nuss GW. 1962. Carrageenan-induced edema in hind paws of the rats as an assay for antiinflammatory drugs. Proc. Soc. Exp. Bio. Med. 111:544-547.

Yoon WJ., Kim SS., Oh TH., Lee NH., Hyun CG. 2009. Cryptomeria japonica essential oil inhibits the growth of drug-resistant skin pathogens and LPS-induced NO and pro-inflammatory cytokine production. Polish J. Microbiol.58:61-68. 